\title{
PŮSOBNOST LISTINY ZÁKLADNÍCH PRÁV EU V KONTEXTU JUDIKATURY ÚSTAVNÍHO SOUDU ČR*
}

\author{
MAGDALÉNA SVOBODOVÁ
}

\begin{abstract}
The scope of application of the Charter of Fundamental Rights of the EU in the context of the case-law of the Constitutional Court of the Czech Republic

The paper focuses on the issue of the limited scope of application of the Charter of Fundamental Rights of the EU in the case-law of the Constitutional Court of the Czech Republic. This issue is new for the national courts since the Convention for the Protection of Human Rights and Fundamental Freedoms as well as other international human rights instruments are not limited in this respect. First, the author analyses certain aspects of the case-law of the Court of Justice of the EU relating to the Article 51 (1) of the Charter and points out the inconsistency of the case-law of the EU Court of Justice. Consequently, she analyses decisions of the Constitutional Court from the perspective of how the court takes account of the limited scope of application of the Charter. The Constitutional Court does not always apply the Charter in line with its Article 51 (1). Nevertheless, from material point of view rights of individuals are probably not affected.
\end{abstract}

Key words: Charter of Fundamental Rights of the EU; Court of Justice of the EU; Constitutional Court of the Czech Republic; protection of fundamental rights

Klíčová slova: Listina základních práv EU; Soudní dvůr EU; Ústavní soud ČR; ochrana základních práv

DOI: $10.14712 / 23366478.2018 .33$

\section{1. ÚVOD}

Listina základních práv Evropské unie (dále také „Listina“ či „LZPEU“) představuje v jistém slova smyslu vyvrcholení vývoje ochrany základních práv na úrovni EU. Tento vývoj započal Soudní dvůr, který dovodil existenci ochrany základních práv jako obecné právní zásady komunitárního práva na přelomu 60. a 70. let minulého století. Při své rozhodovací činnosti, často v rámci řízení o předběžných otázkách, pak Soudní dvưr čerpal zejména z Úmluvy o ochraně lidských práv a základních svobod (dále jen „Úmluva“) a z ústavních tradic společných členským státům. Při rozhodování jednotlivých př́ípadů souvisejících s ochranou základních práv na vnitrostátní úrovni

* Tento výstup vznikl v rámci projektu Specifického vysokoškolského výzkumu 2017-2019 s názvem „Právní vědomí: pojem, formování, účinky se zvláštním zřetelem k působení Listiny základních práv Evropské unie na právní vědomí v České republice“, č. 260 361, řešeného na Právnické fakultě Univerzity Karlovy. 
přitom zkoumal, zda má př́pad evropský prvek, a je tedy dána jeho jurisdikce. Tento př́stup vyplývá z rozdělení pravomocí mezi Evropskou unií (dříve Evropským společenstvím, resp. Evropským hospodářským společenstvím) na straně jedné a členskými státy na straně druhé.

Na uvedený vývoj následně navázala i Listina, která je určena na prvním místě orgánům EU a jejíž působnost je ve vztahu k členským státům omezena v čl. 51 odst. 1 $\mathrm{s}$ ohledem na zmíněnou dělbu pravomocí mezi EU a členskými státy. Podle tohoto článku jsou ustanovení Listiny určena ,členským státům, výhradně pokud uplatňují právo Unie“. Toto ustanovení je předmětem značné pozornosti ze strany odborné veřejnosti, prričemž od počátku vyvolávalo řadu otázek, co tato formulace přesně znamená. Stěžejní je v této souvislosti judikatura Soudního dvora EU (dále také „SDEU“), který citované ustanovení interpretuje. Ta však není zcela konzistentní, některá rozhodnutí jsou překvapivá, a nelze proto ř́ci, že by mantinely použití Listiny na vnitrostátní úrovni byly jednoznačně nastaveny. To samozřejmě vnitrostátním soudům ztěžuje aplikaci Listiny při jejich rozhodovací činnosti.

Tento př́íspěvek se zaměřuje na otázku, jak se Ústavní soud České republiky (dále také „Ústavní soud“ či „ÚS ČR“) vyrovnává s omezenou působností Listiny, když Úmluva či jiné podobné lidskoprávní dokumenty takové omezení neobsahují. Ústavní soud byl zvolen z toho důvodu, že rozhoduje ve věcech ochrany ústavně zaručených základních práv a svobod a zkoumá též dodržování mezinárodních smluv o lidských právech a základních svobodách, jakož i Listiny. Autorka nejprve rozebírá některé aspekty judikatury Soudního dvora EU k čl. 51 odst. 1 LZPEU a následně rozhodnutí Ústavní soudu z hlediska toho, jak zohledňuje omezenou působnost Listiny. Zda Ústavní soud aplikuje Listinu vždy, když je dána její působnost, a naopak neaplikuje tehdy, když $\mathrm{v}$ dané věci není uplatňováno právo Unie, a jaké z toho plynou následky.

\section{PU゚SOBNOST LISTINY V JUDIKATUŘE SOUDNÍHO DVORA EU}

Jak již bylo řečeno výše, Listina je oproti Úmluvě či jiným lidskoprávním úmluvám specifická svou omezenou působností na úrovni členských států. Důvodem je rozdělení pravomocí mezi EU a její členské státy, které čl. 51 odst. 1 LZPEU reflektuje. Při vzniku Listiny se některé členské státy obávaly omezení své suverenity z toho důvodu, že by Soudní dvůr EU zacházel s Listinou jako s „federalizujícím prostředkem“ a v důsledku toho nahradil základní práva v národních ústavách jednotným - unijním standardem. ${ }^{1}$

Již samotná formulace tohoto ustanovení je však v mnoha ohledech nejasná. V první řadě bývá upozorňováno na skutečnost, že jednotlivé jazykové verze tohoto článku

\footnotetext{
1 Viz k tomu LENAERTS, K.: Exploring the Limits of the EU Charter of Fundamental Rights. European Constitutional Law Review, 2012, č. 8, s. 376 či BUCHER, S.: Die Bindung der Mitgliedstaaten an die EU-Grundrechtecharta bei Ermessensspielräumen, insbesondere in Fällen der Richtlinienumsetzung und unter Berücksichtigung der Folgerechtsprechung zu „Åkerberg Fransson“. Zeitschrift für Europarechtliche Studien, 2016, č. 2, s. 204. K dané problematice srov. též HAMULÁK, O. - MAZÁK, J.: The Charter of Fundamental Rights of the European Union vis-à-vis the Member States - Scope of its Application in the view of the CJEU. Czech Yearbook of Public \& Private International Law, 2017, č. 8, s. 162 a násl.
} 
se liší. Podle české verze jsou ustanovení Listiny určena „,̌lenským státům, výhradně pokud uplatňují právo Unie“. Podle slovenské verze jsou určena členským státům, „ak vykonávajú právo Únie“, v anglické verzi „when they are implementing Union law“, německé „,bei der Durchführung des Rechts der Union“, francouzské „lorsqu'ils mettent en œuvre le droit de l'Union“. Je proto třeba zaměřit se na výklad tohoto ustanovení v judikatuře Soudního dvora EU. Soudní dvůr v rozsudku Fransson upřesňuje, že „,[p]oužitelnost unijního práva s sebou nese použitelnost základních práv zaručených Listinou“. ${ }^{2}$ Generální advokát Bobek ve svém stanovisku ve věci Ispas uvádí, že „V príípadě, kdy vnitrostátní právní úprava spadá do působnosti unijního práva, musí být respektována základní práva Evropské unie: nemůže nastat př́ipad, který by spadal pod unijní právo, a uvedená práva by se neuplatnila. Základní práva jsou totiž stínem“ unijního práva."3

V judikatuře Soudního dvora EU lze sledovat tendence rozšiřovat působnost Listiny. Je třeba nicméně uvést, že rozšiřování působnosti Listiny, resp. unijního práva a ruku v ruce s tím rozšiřování pravomocí Unie (v této souvislosti minimálně Soudního dvora EU) je zřejmě přirozeností Evropské unie jako mezinárodní organizace. Tento fenomén lze pozorovat i u jiných mezinárodních organizací. Napřs. Mezinárodní soudní dvůr jako orgán Organizace spojených národů (dále jen „OSN“) krátce po jejím vzniku dovodil v posudku Náhrada škod utrpěných ve službách $O S N$ z roku 1949 existenci implicitních kompetencí OSN, které nebyly v Chartě OSN výslovně uvedeny. ${ }^{4}$ Dalším př́íkladem je prrijetí rezoluce Rady bezpečnosti OSN č. 827 z 25. 5. 1993, kterou byl zř́zen Mezinárodní trestní tribunál pro bývalou Jugoslávii, přestože Charta OSN toto výslovně neumožňuje. Tento soud pak v př́padu Tadic z roku 1995 dospěl k závěru, že jeho zř́izení patří mezi „opatř̌ení nezahrnující užití ozbrojené síly“ ve smyslu čl. 41 Charty OSN, i když v Chartě není explicitně uvedeno oprávnění Rady bezpečnosti zřizovat trestní tribunály. ${ }^{5} \mathrm{~V}$ této souvislosti je ale třeba poznamenat, že fenomén rozšiřování pravomocí mezinárodní organizace není u žádného jiného subjektu tak silný, jako právě u EU.

Cílem tohoto př́spěvku není důkladná analýza výkladu čl. 51 odst. 1 LZPEU ze strany Soudního dvora EU, nebot' to jednak přesahuje možnosti tohoto článku, jednak je této problematice již věnována celá řada odborných publikací. ${ }^{6}$ Autorka chce poukázat především na heterogenitu přístupu Soudního dvora EU a z ní vyplývající obtížnost orientovat se $\mathrm{v}$ působnosti Listiny pro vnitrostátní soudy.

2 C-617/10 Åklagaren proti Hans Åkerberg Fransson, ECLI:EU:C:2013:280, bod 21.

3 Stanovisko generálního advokáta Bobka ve věci C-298/16 Teodor Ispas a Anduţa Ispas v. Direcţia Generală a Finanţelor Publice Cluj, ECLI:EU:C:2017:650.

4 Viz k tomu např. MALENOVSKÝ, J.: Mezinárodni právo veřejné, jeho obecná část a poměr $k$ jiným právním systémuim, zvláště k právu českému. Brno: Doplněk, 2008, s. 149.

5 Bod 34 rozsudku. Viz ŠTURMA, P. CASEBOOK. Výběr prípadi̊ z mezinárodního práva veřejného. Praha: Univerzita Karlova, Právnická fakulta, 2015, s. 184.

6 Za všechny lze odkázat na komentáre k Listině PEERS, S. - HARVEY, T. - KENNER, J. - WARD, A. (eds).: The EU Charter of Fundamental Rights. A Commentary. Oxford: C. H. Beck, Hart, Nomos, 2014 či MEYER, J. (ed): Charta der Grundrechte der Europäischen Union. Baden-Baden: Nomos, 2014. Viz též MAZÁK, J. - JÁNOŠÍKOVÁ, M. a kol.: Charta základných práv Európskej únie v konaniach pred orgánmi súdnej ochrany v Slovenskej republike. Košice: Univerzita Pavla Jozefa Šafárika v Košiciach, 2016, s. 30 a násl. 
Specifikem Listiny je její př́iloha nazvaná „Vysvětlení k Listině základních práv“ (dále jen „Vysvětlení“), která slouží jako interpretační pomůcka. K čl. 51 odst. 1 se zde uvádí, že požadavek respektovat základní práva definovaná v rámci Unie je pro členské státy závazný, „pouze jednají-li v oblasti působnosti práva Unie“. Vysvětlení odkazují na některá starší rozhodnutí Soudního dvora EU, na něž Listina navazuje, konkrétně na rozhodnutí Wachauf, ERT, Annibaldi a Karlsson. V rozsudku Wachauf ${ }^{7}$ Soudní dvůr uvádí, že komunitární nařízení, které se ve věci použije, nechává vnitrostátním orgánům dostatečně široký prostor pro to, aby je tyto orgány aplikovaly způsobem slučitelným s požadavky na ochranu základních práv. ${ }^{8}$ Ve věci $E R T^{9}$ Soudní dvưr konstatoval, že pokud členské státy přijímají opatření omezující volný pohyb služeb, musí tak činit v souladu s ochranou základních práv (zde v souladu se svobodou projevu ve smyslu čl. 10 Úmluvy)..$^{10} \mathrm{~V}$ rozsudku Karlsson ${ }^{11}$ Soudní dvůr připomíná, že požadavky na ochranu základních práv vyplývajících z práva Společenství (v uvedeném př́ípadě princip rovnosti a nediskriminace) jsou závazné pro členské státy také tehdy, když členské státy provádějí komunitární pravidla. V rozhodnutí Annibaldi ${ }^{12}$ naopak Soudní dvůr dospěl k závěru, že daná situace nespadá do působnosti komunitárního práva, a soud proto nemá jurisdikci rozhodnout o položené předběžné otázce..$^{13} \mathrm{~V}$ této věci se jednalo o to, že pan Annibaldi chtěl zasadit ovocný sad zasahující do území italského přírodního parku, což mu italské úřady nepovolily z důvodu ochrany prírody. Pan Annibaldi se následně bránil s argumentací, že se jedná zásah do jeho vlastnických práv. Soudní dvưr však konstatoval, že ve věci nelze aplikovat žádné komunitární pravidlo, přičemž relevantní vnitrostátní právo ani neprovádí komunitární právo. ${ }^{14}$ Lze shrnout, že Vysvětlení nastiňují některé typické situace, v nichž se bude či naopak nebude Listina aplikovat na vnitrostátní úrovni. Členské státy jsou povinny aplikovat nařízení způsobem konformním s Listinou, opatření omezující vnitřní trh musí být slučitelná s Listinou a dále členské státy musí provádět unijní pravidla (např. směrnice) v souladu s Listinou. Působnost Listiny naopak nebude dána $\mathrm{v}$ př́padě, kdy členský stát neprovádí právo Unie či ve věci nelze aplikovat žádná unijní pravidla.

Na uvedenou judikaturu Soudní dvůr EU následně navázal při výkladu (právně závazné) Listiny. Lze konstatovat, že prŕístup Soudního dvora EU je různorodý. Zaprvé, v řadě př́padů soud aplikuje Listinu na základě adekvátního výkladu čl. 51 odst. 1. Zadruhé, Soudní dvůr EU aplikuje Listinu v některých př́ípadech na základě extenzivního výkladu tohoto ustanovení. Zatřetí, lze se setkat i s rozhodnutími založenými naopak na restriktivní interpretaci její působnosti. Začtvrté, v některých př́ípadech soud vůbec Listinu neaplikoval, ačkoli byla dána její působnost.

\footnotetext{
C-5/88 Hubert Wachaufv Bundesamt für Ernährung und Forstwirtschaft, ECLI:EU:C:1989:321.

Bod 22 rozsudku Wachauf.

9 C-260/89 Elliniki Radiophonia Tiléorassi AE, ECLI:EU:C:1991:254.

10 Body 43 a 45 rozsudku ERT.

11 C-292/97 Kjell Karlsson, ECLI:EU:C:2000:202.

12 C-309/96 Daniele Annibaldi proti Sindaco del Comune di Guidonia a Presidente Regione Lazio, ECLI: EU:C:1997:631.

13 Body 21-24 rozsudku Annibaldi.

14 Viz k tomu též pozdější rozsudek C-206/13 Cruciano Siragusa v. Regione Sicilia - Soprintendenza Beni Culturali e Ambientali di Palermo, ECLI:EU:C:2014:126.
} 
Existuje samozřejmě řada rozhodnutí SDEU aplikujících Listinu na základě adekvátního výkladu čl. 51 odst. 1. Př́kladem z poslední doby je rozsudek Egenberger. ${ }^{15}$ Vera Egenberger se ucházela o pracovní pozici nabízenou Evangelisches Werk. V. Egenberger však neuspěla a domnívala se, že její přihláška byla zamítnuta z důvodu, že je bez vyznání. Následně požadovala zaplacení náhrady způsobené újmy od Evangelisches Werk z důvodu diskriminace. V rámci řizení o předběžné otázce se Soudní dvůr zabýval jednak výkladem směrnice 2000/78, kterou se stanoví obecný rámec pro rovné zacházení v zaměstnání a povolání, ${ }^{16}$ jednak výkladem Listiny (zejm. čl. 21 a 47). K působnosti Listiny Soudní dvůr uvádí mimo jiné, že se použije na spor z důvodu aplikace německého zákona provádějícího směrnici 2000/78. ${ }^{17}$

Podobně v řadě azylových př́padů rozhodovaných Soudním dvorem, které jsou v současnosti aktuální problematikou, bývá působnost Listiny dána, nebot’ tato oblast je bohatě regulována unijním sekundárním právem, a to i pokud jde o procesní pravidla. Jako př́klad lze uvést rozsudek $F .^{18}$ Žadatel o azyl ve své žádosti uváděl, že se důvodně obává pronásledování v zemi svého původu z důvodu homosexuality. V řízení o udělení azylu byly provedeny psychologické testy, na jejichž základě př́slušný úřad odmítl žádost o azyl. Žadatel posléze namítal, že psychologické testy vážně porušují jeho základní práva. Soudní dvưr v ř́izení o předběžné otázce vykládal tzv. kvalifikační směrnici ${ }^{19}$ a Listinu (zejm. čl. 7). Za pozornost stojí, že Soudní dvůr se vůbec nezabýval otázkou, zda je dána působnost Listiny, a považoval to patrně za samozřejmé.

V některých rozhodnutích je ovšem př́stup SDEU extenzivní. $Z$ doby před nabytím závaznosti Listiny lze zmínit např. rozsudek Borelli ${ }^{20}$ či sporný rozsudek Steffensen. ${ }^{21}$ Příslušný německý úřad uložil panu Steffensenovi pokutu za nedodržení požadavků na kvalitu klobás, jejichž vzorek úřad odebral z maloobchodu a následně analyzoval z hlediska kvality. Panu Steffensenovi však nebylo umožněno požádat o druhé stanovisko analyzující kvalitu potravin, jak stanovila komunitární směrnice. Soudní dvůr v řízení o předběžné otázce řešil mj. to, zda lze za této situace ve vnitrostátním řízení použít stanovisko úřadu jako důkaz. Věc posuzoval také z hlediska ochrany základních práv, zejm. práva na spravedlivý proces, přestože na úvod svého rozsudku uvádí, že př́ípustnost důkazů ve vnitrostátním ř́izení není upravena žádným komunitárním pravidlem. ${ }^{22}$ Rozsudek Steffensen je tak dokladem toho, jak Soudní dvůr rozšiřuje působnost komunitárního (nyní unijního) práva i do oblasti vnitrostátního procesního práva.

15 C-414/16 Vera Egenberger proti Evangelisches Werk für Diakonie und Entwicklung eV, ECLI:EU: C:2018:257.

16 Směrnice Rady 2000/78/ES ze dne 27. 11. 2000, kterou se stanoví obecný rámec pro rovné zacházení v zaměstnání a povolání, Úř. věst. L 303, 2. 12. 2000, s. 16-22.

17 Bod 49 rozsudku Egenberger.

18 C-473/16 F proti Bevándorlási és Állampolgársági Hivatal, ECLI:EU:C:2018:36.

19 Směrnice Evropského parlamentu a Rady 2011/95/EU ze dne 13. prosince 2011 o normách, které musí splňovat státní př́islušníci třetích zemí nebo osoby bez státní příslušnosti, aby mohli požívat mezinárodní ochrany, o jednotném statusu pro uprchlíky nebo osoby, které mají nárok na doplňkovou ochranu, a o obsahu poskytnuté ochrany, Úř. věst. L 337, 20. 12. 2011, s. 9-26.

20 C-97/91 Oleificio Borelli SpA proti Komisi Evropských společenství, ECLI:EU:C:1992:491.

21 C-276/01 Joachim Steffensen, ECLI:EU:C:2003:228. Viz k tomu též BUCHER, S., op cit., s. 209.

22 Bod 62 rozsudku Steffensen. 
Velmi známý a často komentovaný bývá rozsudek Fransson. Soudní dvůr (po nabytí závaznosti Listiny) v něm dovodil, že daňové sankce upravené vnitrostátním právem představují provedení př́íslušné unijní směrnice týkající se DPH, čímž je dána působnost Listiny, a to přesto, že relevantní švédská právní úprava byla přijata již před vydáním této směrnice. Rozsudek byl v nedávné době potvrzen rozhodnutím $M e n c i^{23}$. Z poslední doby lze zmínit rozsudek Delvigne ${ }^{24}$. Ve věci šlo o to, že francouzský státní občan byl odsouzen za vraždu a jedním z uložených trestů bylo i doživotní zbavení občanských práv včetně práva volit a být volen do Evropského parlamentu. Soudní dvůr v rozsudku dospěl $\mathrm{k}$ závěru, že Francie v tomto př́padě uplatňuje unijní právo, a je tedy dána působnost Listiny, přestože podle předchozí judikatury konkretizace osob oprávněných volit či být volen do Evropského parlamentu spadala do pravomoci členských států. ${ }^{25}$

V některých prrípadech se lze setkat i se spíše restriktivním prrístupem SDEU, např. ve věci Dano. ${ }^{26}$ Rozsudek je známý především snahou Soudního dvora omezit tzv. sociální turistiku. Tomu odpovídá $\mathrm{i}$ jeho př́stup $\mathrm{k}$ aplikaci Listiny $\mathrm{v}$ dané věci. Jedna z předběžných otázek položených německým soudem se týkala výkladu článků 1,20 a 51 LZPEU v souvislosti s poskytováním neprííspěvkových peněžitých dávek ve smyslu tzv. koordinačního nařízení27 občanům Unie. Soudní dvůr dospěl k závěru, že př́islušné nařízení neurčuje hmotněprávní podmínky pro existenci nároku na uvedené dávky. Je tedy věcí zákonodárce členského státu, aby tyto podmínky určil, přičemž při stanovování těchto podmínek členské státy neuplatňují právo Unie. Soudní dvưr proto nemá pravomoc odpovědět na položenou předběžnou otázku. ${ }^{28}$ Jeho závěr je tak opačný než ve výše zmiňovaném př́ípadu Delvigne. Rozhodovaná věc měla navíc poměrně zřetelný evropský prvek, protože E. Dano, která o př́íslušné dávky žádala, byla rumunskou státní př́slušnicí (a tedy občankou Unie), jež vykonala volný pohyb z Rumunska do Německa.

Některé př́pady ukazují, že Soudní dvůr není v aplikaci Listiny zcela důsledný. V př́padu Sorondo ${ }^{29} \mathrm{se} \mathrm{G}$. S. Sorondo ucházel o místo u baskické policie, avšak neuspěl z důvodu, že byl starší 35 let. Pan Sorondo se následně bránil proti údajné diskriminaci na základě věku u španělského soudu. Přestože se odvolával i na Listinu, španělský soud položil Soudnímu dvoru předběžnou otázku týkající se pouze výkladu směrnice 2000/78 a Soudní dvůr si s výkladem této směrnice vystačil. V konfrontaci s výše zmiňovaným př́padem Egenberger je přitom zřejmé, že v něm šlo také o výklad této směrnice, který však Soudní dvůr doplnil o výklad relevantních ustanovení Listiny (na výklad Listiny se přitom vnitrostátní soudy neptaly ani v jednom př́ípadě). Lidskoprávní rozměr obou př́padů je zřejmý.

23 C-524/15 Trestní řizení proti Lucovi Mencimu, ECLI:EU:C:2018:197.

24 C-650/13 Thierry Delvigne proti Commune de Lesparre-Médoc, Préfet de la Gironde, ECLI:EU: C:2015:648.

25 Francouzská právní úprava přitom nebyla Soudním dvorem shledána v rozporu s unijním právem, což kontrastuje s judikaturou Evropského soudu pro lidská práva ve věcech omezování volebního práva vězňů. Viz k tomu KORNEZOV, A.: The right to vote as an EU fundamental right and the expanding scope of application of the EU Charter of fundamental rights. The Cambridge Law Journal, 2016, č. 1, s. 24-27.

26 C-333/13 Elisabeta Dano a Florin Dano proti Jobcenter Leipzig, ECLI:EU:C:2014:2358.

27 Nařízení Evropského parlamentu a Rady (ES) č. 883/2004 ze dne 29. dubna 2004 o koordinaci systémů sociálního zabezpečení, Úřr. věst. L 166, 30. 4. 2004.

28 Body 89-92 rozsudku Dano.

29 C258/15 Gorka Salaberria Sorondo v. Academia Vasca de Policía y Emergencias, ECLI:EU:C:2016:873. 
Lze uzavřít, že Soudní dvůr EU ve své rozhodovací činnosti podrobněji specifikuje situace, v nichž má být Listina aplikována na vnitrostátní úrovni. Existují však rozhodnutí, jimiž rozšiřuje působnost Listiny oproti své předchozí judikatuře, či naopak rozhodnutí zužující použití Listiny. V některých případech Listinu neaplikuje, ačkoli má věc lidskoprávní dimenzi. Jeho judikaturu tak nelze považovat za zcela konzistentní.

\section{PŘÍSTUP ÚSTAVNÍHO SOUDU ČR K PŮSOBNOSTI LISTINY}

Na úvod je třeba alespoň stručně zmínit přístup Ústavního soudu k Listině. Ústavní soud je povinen aplikovat Listinu s ohledem na její právní závaznost, což také činí ve své rozhodovací činnosti (v řízeních o konkrétní či abstraktní kontrole ústavnosti). Listiny se tedy lze dovolávat $\mathrm{v}$ ř́zení před Ústavním soudem. Ústavní soud však Listinu nepovažuje za součást ústavního pořádku ČR, nebot' není ústavním zákonem ${ }^{30}$ a není ani považována za ratifikovanou a vyhlášenou mezinárodní smlouvu o lidských právech a základních svobodách ve smyslu čl. 10 Ústavy, kterou by Ústavní soud zahrnul do rámce ústavního pořádku. ${ }^{31}$ Listina se pohybuje v jakési „šedé zóně“, nebot’ Ústavní soud výslovně konstatuje, že sice není referenčním kritériem ústavního pořád$\mathrm{ku}$, ale přesto je dalším kritériem přezkumu ústavnosti. ${ }^{32} \mathrm{~V}$ řízeních před Ústavním soudem ovšem nelze argumentovat výlučně rozporem s Listinou, stěžovatel či navrhovatel musí v prvé řadě dovozovat rozpor s ústavním pořádkem (tj. zejména s Listinou základních práv a svobod ${ }^{33}$ ). Tomu odpovídají i výroky nálezů Ústavního soudu, v nichž je konstatován rozpor s Listinou základních práv a svobod, př́íp. s Úmluvou nebo jinou lidskoprávní smlouvou, nikdy však výslovně s Listinou. ${ }^{34}$

Jak již bylo řečeno, Ústavní soud tedy Listinu použivá ve své rozhodovací činnosti, její role ovšem bývá při rozhodování spíše doplňková. Je aplikována vedle Listiny základních práv a svobod, Úmluvy či dalších lidskoprávních instrumentů. V Evropské unii se přitom nejedná o ojedinělý př́stup, Agentura Evropské unie pro lidská práva uvádí, že tento př́istup vnitrostátních soudů $\mathrm{k}$ Listině je běžný. ${ }^{35} \mathrm{Z}$ hlediska toho, jak se Ústavní soud vyrovnává s omezenou působností Listiny, můžeme jeho rozhodnutí rozdělit do tř́i skupin. V první skupině jsou rozhodnutí, v nichž je Listina aplikována v souladu se svým čl. 51 odst. 1, nebot' př́ípad má unijní dimenzi. V druhé skupině jsou rozhodnutí, v nichž je Listina aplikována, ačkoli její působnost není dána. Ve třetí skupině jsou rozhodnutí, kdy Listina aplikována není, přestože by v souladu s čl. 51 odst. 1 měla

30 Resp. není výslovně označena za součást ústavního pořádku, srov. čl. 112 odst. 1 ústavního zákona č. 1/1993 Sb., Ústava České republiky, v platném znění (dále jen „Ústava“).

31 Nález ÚS ČR ze dne 25. 6. 2002, sp. zn. Pl. ÚS 36/01.

32 Viz nález ÚS ČR ze dne 19. 5. 2015, sp. zn. Pl. ÚS 14/14 Ústavnost pětiprocentní uzavírací klauzule pro volby do Evropského parlamentu a usnesení ÚS ČR ze dne 8. 6. 2016, sp. zn. II. ÚS 1537/16.

33 Usnesení předsednictva ČNR č. 2/1993 Sb., o vyhlášení Listiny základních práv a svobod jako součásti ústavního pořádku České republiky, v platném znění.

34 Bliže k tomu viz SVOBODOVÁ, M.: Listina základních práv EU v judikatuře Ústavního soudu ČR. Právní rozhledy, 2017, č. 23-24, s. 823-828. Srov. též HAMULÁK, O.: Listina základních práv Evropské unie jako okolí ústavního pořádku české republiky. Acta Iuridica Olomucensia, 2015, č. 3, s. 7-30.

35 Viz zpráva o lidských právech z roku 2018, s. 37. Zpráva je dostupná online na http://fra.europa.eu/en /publication/2018/fundamental-rights-report-2018 [cit. 6. 6. 2018]. 
být použita. Rozhodnutí, v nichž je Listina aplikována, lze dále členit podle toho, zda Ústavní soud odůvodňuje použití Listiny. V některých př́padech Ústavní soud odkazuje na čl. 51 odst. 1 LZPEU, v jiných se Ústavní soud tímto ustanovením nijak nezabývá.

Pokud jde o první skupinu rozhodnutí, v nichž je Listina aplikována v souladu s čl. 51 odst. 1, lze zmínit nález Podmínky zápisu absolventa zahraniční právnické fakulty do seznamu koncipientů. ${ }^{36}$ Př́ípad měl jednoznačný unijní rozměr, nebot' se týkal uznávání profesní kvalifikace, což je problematika regulovaná sekundárním právem, která je též často předmětem rozhodovací činnosti Soudního dvora EU. V dané věci se absolvent polské Jagellonské univerzity domáhal zápisu do seznamu koncipientů vedeného Českou advokátní komorou. Ústavní soud rozebírá, že s ohledem na článek 51 má být Listina aplikována. „Na posuzovanou věc dopadá také unijní právo. Konkrétně jde o směrnici Evropského parlamentu a Rady 2005/36/ES ze dne 6. července 2005 o uznávání odborných kvalifikací (dále jen ,směrnice'). S ohledem na čl. 51 Listiny základních práv EU, který zakotvuje zásadu ,pokud se použije unijní právo, použije se i Listina základních práv EU` (,if EU law applies, then Charter applies'), je třeba vycházet i z jejího čl. 15.“37

Jako další př́klad lze uvést nález pléna Ústavního soudu Ústavnost pětiprocentní uzaviraci klauzule pro volby do Evropského parlamentu. ${ }^{38}$ Ústavní soud konstatuje následující. „Jelikož přijímání vnitrostátních implementačních předpisů k Aktu [rozhodnutí 76/787/ESUO, EHS, Euratom o Aktu o volbě poslanců Evropského parlamentu ve všeobecných přímých volbách - pozn. autorky], včetně vyplnění jím poskytnutého prostoru pro legislativní uvážení národního zákonodárce, je ,uplatňováním‘ unijního práva ve smyslu čl. 51 odst. 1 Listiny základních práv Evropské unie (dále též jen ,LZPEU‘), mohou se na přezkumu ústavnosti těchto předpisů v členských státech spolu $\mathrm{s}$ referenčními kritérii ústavního pořádku $\mathrm{v}$ zásadě podílet - podle své povahy - také ustanovení LZPEU, at’ už ,prostupováním‘ do ústavního pořádku nebo př́mou aplikací v př́padě vyšší úrovně jimi poskytované ochrany (čl. 53 LZPEU).“"39

V nálezu III. ÚS 2782/14, který se týkal náhrady za zpoždění letu, nepoložil obecný soud předběžnou otázku Soudnímu dvoru, čímž se podle názoru Ústavního soudu dopustil porušení Listiny základních práv a svobod (práva na spravedlivý proces a práva na zákonného soudce). K aplikaci Listiny uvádí soud následující. „Je třeba připomenout, že př́má aplikace Nařízení je ,uplatňováním“ práva Unie ve smyslu čl. 51 odst. 1 Listiny základních práv Evropské unie, která se na projednávaný př́ípad vztahuje, i když se této okolnosti stěžovatelka nedovolává, takže spolu s porušením výše uvedených ustanovení ústavního pořádku České republiky dochází s ohledem na povinnost př́mé aplikace Nařízení i k porušení práva na účinnou právní ochranu a spravedlivý proces ve smyslu čl. 47 Listiny základních práv Evropské unie.“

Lze ovšem nalézt i řadu rozhodnutí Ústavní soudu, v nichž soud ani stručně nezdůvodňuje použití Listiny. Př́kladem takového př́stupu je nález Porušení práva na osobní svobodu a rodinný život při zajištěni cizinců provedeného bez zákonného podkladu. ${ }^{40}$

36 Nález ÚS ČR ze dne 25. 10. 2016, sp. zn. II. ÚS 443/16.

37 Bod 30 nálezu Podmínky zápisu absolventa zahraniční právnické fakulty do seznamu koncipientů.

38 Citován výše. Dalším příkladem je usnesení ÚS ČR ze dne 8. 6. 2016, sp. zn. II. ÚS 1537/16 či nález ÚS ČR ze dne 20. 11. 2014, sp. zn. III. ÚS 2782/14.

39 Bod 47 nálezu Ústavnost pétiprocentni uzavírací klauzule pro volby do Evropského parlamentu.

40 Nález ÚS ČR ze dne 10. 5. 2017, sp. zn. III. ÚS 3289/14. 
V daném př́padě se stěžovatelé - žadatelé o azyl - bránili proti svému zajištění v Zařízení pro zajištění cizinců Bělá-Jezová. Působnost Listiny byla v rozhodované věci založena, protože se jednalo o azylovou věc regulovanou unijním právem. Ústavní soud však na Listinu jen stručně odkazuje ${ }^{41}$ bez zhodnocení důvodů pro její použití. Jak již bylo nicméně řečeno, $\mathrm{s}$ tímto prístupem se lze setkat i v judikatuře SDEU.

V některých př́ípadech Ústavní soud patrně považuje použití Listiny za samožrejmé, když odkazuje na př́ílušná unijní pravidla. Př́kladem je nález ÚS ČR ze dne 14. 4. 2016, sp. zn. II. ÚS 143/16, v němž Ústavní soud explicitně nevysvětluje, proč aplikuje Listinu. V uvedeném př́padě bylo proti stěžovatelce dlouhodobě žijící v Německu zahájeno trestní stíhání v České republice pro zvlášt’ závažný zločin. Trestní stíhání bylo zahájeno navzdory tomu, že stěžovatelka byla za tento trestný čin již předtím odsouzena soudem v Německu s tím, že ve vztahu k některým skutkům německý státní zástupce trestní stíhání stěžovatelky zastavil. Stěžovatelka se bránila proti postupu českých orgánů činných v trestním řízení s argumentací, že porušily zásadu ne bis in idem. Ústavní soud odkazuje na čl. 50 Listiny a na relevantní pravidla unijního práva (čl. 54 Schengenské prováděcí úmluvy a judikaturu Soudního dvora EU), nikoli však na čl. 51 odst. 1 LZPEU. V nálezu K protiústavnosti výluky soudního přezkumu u pozastavení výplaty části dotace ${ }^{42}$ Ústavní soud dospěl k závěru, že vyloučení rozhodnutí o pozastavení dotace spolufinancované $\mathrm{z}$ rozpočtu EU ze soudního přezkumu je v rozporu s Listinou základních práv a svobod. Ústavní soud odkazuje na unijní nařízení a judikaturu Soudního dvora EU a zmiňuje též možný rozpor s Listinou, neodůvodňuje však její použití.

Druhou skupinu tvoří rozhodnutí, kdy je Listina aplikována, ačkoli její působnost není dána. Př́kladem takového rozhodnutí je nález Zákaz konání shromáždění z důvodu zvláštni ochrany zájmu dětí. ${ }^{43} \mathrm{~V}$ dané věci zakázal Městský úřad v Chrastavě konat shromáždění, jehož účelem měla být demonstrace za zastavení umělých potratů. Demonstrace měla probíhat formou informačních panelů s drastickými vyobrazeními vystavených v blízkosti základní školy. V nálezu je na Listinu (čl. 24 týkající se práv dětí) jen stručně odkázáno, Ústavní soud však její aplikaci nevysvětluje, přičemž př́ípad nemá žádný zjevný unijní rozměr. Podobným rozhodnutím je Jizda nezletilého načer$n o,{ }^{44} \mathrm{v}$ němž se stěžovatelka bránila proti vymáhání pohledávky vzniklé $\mathrm{v}$ důsledku toho, že jako nezletilá jela několikrát bez platné jízdenky městskou hromadnou dopravou. V nálezu se odkazuje také na čl. 24 LZPEU, opět bez odůvodnění použití Listiny a bez viditelné souvislosti s unijním právem.

Do této kategorie patří též některá rozhodnutí týkající se ochrany spotřebitele, v nichž Ústavní soud odkazuje na čl. 38 LZPEU obsahující požadavek vysoké úrovně ochrany spotřebitele v politikách EU, aniž by však zdůvodnil, proč má být Listina aplikována. ${ }^{45}$ Jen prostý fakt, že se v rozhodované věci jedná o právní vztah mezi spotřebitelem a obchodníkem, nezakládá ještě působnost Listiny. Ochrana spotřebitele je sice

41 Srov. bod 39 nálezu Porušeni práva na osobni svobodu a rodinný život př́ zajištění cizinců provedeného bez zákonného podkladu.

42 Nález ÚS ČR ze dne 16. 6. 2015, sp. zn. Pl. ÚS 12/14.

43 Nález ÚS ČR ze dne 5. 5. 2015, sp. zn. II. ÚS 164/15.

44 Nález ÚS ČR ze dne 15. 2. 2017, sp. zn. I. ÚS 1775/14.

45 Srov. usnesení ÚS ČR ze dne 14. 3. 2017, sp. zn. I. ÚS 3049/16 či usnesení ÚS ČR ze dne 17. 1. 2017, sp. zn. I. ÚS 1081/16. 
politikou Unie, avšak jedná se o politiku ve sdílené pravomoci Unie a členských států, která není regulována výlučně unijním právem. Ve spotřebitelských sporech proto bude třeba zejména zkoumat, zda relevantní česká právní úprava provádí unijní směrnice na ochranu spotřebitele. V takovém prípadě bude dána působnost Listiny. Pokud se jedná o vnitrostátní legislativu bez vazby na unijní právo (a př́pad ani jinak nemá unijní dimenzi), není působnost Listiny založena. V nálezu ÚS ČR ze dne 27. 11. 2017, sp. zn. I. ÚS 1844/17, šlo také o ochranu spotřebitele a naplno se zde projevuje paušalizující podřazení spotřebitelského práva pod právo unijní. „Ochrana spotřebitele je rovněž celoevropským zájmem (srov. čl. 4 Smlouvy o fungování Evropské unie) a spotřebitelské právo, ačkoli působící ve formě vnitrostátních zákonů, má svůj původ ve směrnicové úpravě na unijní úrovni. Při aplikaci právních předpisů v oblasti spotřebitelských vztahů je proto nutné na věc nahlížet také pohledem unijního práva. Pokud totiž vnitrostátní právní úprava spadá do působnosti unijního práva, musí být respektována základní práva Evropské unie a ,nemůže nastat př́pad, který by spadal pod unijní právo, a uvedená práva by se neuplatnila. Základní práva jsou totiž «stínem» unijního práva. ' (...). Aplikovatelnost spotřebitelské právní úpravy tedy vede i k aplikovatelnosti čl. 38 Listiny základních práv EU, který garantuje vysokou úroveň ochrany spotřebitele."46

Konečně lze identifikovat třetí skupinu př́padů, kdy Ústavní soud měl Listinu aplikovat, avšak nepoužil ji. Mezi ně patří nález Ústavního soudu ze dne 18. 9. 2014, sp. zn. III. ÚS 2331/14. Žadatel o mezinárodní ochranu se bránil proti svému přemístění na Maltu s argumentací, že na Maltě není zajištěna dostatečná ochrana základních práv ve vztahu k žadatelům o mezinárodní ochranu. Působnost Listiny byla dána, nebot' ve věci bylo aplikováno unijní nařízení. Přestože se stěžovatel výslovně Listiny domáhal, Ústavní soud ji neaplikoval.

Dále lze zmínit sérii rozhodnutí Ústavního soudu týkající se porušení povinnosti obecného soudu ČR položit předběžnou otázku Soudnímu dvoru. Ústavní soud v nich dospěl $\mathrm{k}$ závěru, ${ }^{47}$ že porušení této povinnosti může znamenat porušení práva na spravedlivý proces či práva na zákonného soudce ve smyslu Listiny základních práv a svobod. Až v nálezu ze dne 20. 11. 2014, sp. zn. III. ÚS 2782/14, Ústavní soud dovodil, že porušením povinnosti položit předběžnou otázku k Soudnímu dvoru došlo i k porušení Listiny.

Jiným prríkladem je nález Nárok klientů zkrachovalé cestovni kanceláře na vrácení plné ceny zájezdu. ${ }^{48} \mathrm{Klienti} \mathrm{zkrachovalé} \mathrm{cestovní} \mathrm{kanceláŕe} \mathrm{se} \mathrm{domáhali} \mathrm{zaplacení}$ pojistného plnění vůči pojišt'ovně ve výši odpovídající plné ceně zájezdu zaplacené cestovní kanceláři. Pojišt'ovna však nevyplatila plnou částku s odůvodněním, že součet všech nároků klientů převýšil limit pojistného plnění sjednaný v rámci pojistné smlouvy. Ohledně zbývající části nároku (jednalo se o bagatelní částku) proto podali žalobu k okresnímu soudu, ten však jejich nároku nevyhověl. Ústavní soud následně konstatoval, že okresní soud neinterpretoval př́slušný zákon provádějící unijní směrnici

\footnotetext{
46 Bod 13 nálezu I. ÚS 1844/17.

47 Viz např. nález ÚS ČR ze dne 8. 1. 2009, sp. zn. II. ÚS 1009/08, nález ÚS ČR ze dne 29. 11. 2011, sp. zn. II. ÚS 1658/11, či nález ÚS ČR ze dne 11. 9. 2012, sp. zn. II. ÚS 2504/10.

48 Nález ÚS ČR ze dne 14. 6. 2016, sp. zn. IV. ÚS 2370/15.
} 
eurokonformním způsobem, čímž došlo k porušení Listiny základních práv a svobod a Úmluvy. ${ }^{49}$ Ústavní soud nezmiňuje Listinu, která však měla být také aplikována.

Nepoužitím Listiny v rozporu s jejím čl. 51 odst. 1 dochází k porušení unijního práva. Je nicméně třeba zdůraznit, že ve všech výše rozebíraných případech je ochrana základních práv jednotlivců zajištěna prostřednictvím Listiny základních práva a svobod a Úmluvy. Z materiálního hlediska tedy patrně nebyli zkráceni na svých právech, nebot' Listina obsahuje $\mathrm{v}$ zásadě standard ochrany základních práv dosažený na vnitrostátní a mezinárodní úrovni.

\section{ZÁVĚR}

Jak vyplývá z výše uvedeného, aplikace Listiny ze strany Ústavního soudu ČR neodpovídá zcela její působnosti. V některých př́ipadech je Listina aplikována nad rámec čl. 51 odst. 1, a Ústavní soud tak rozšiřuje její působnost v českém prostředí. Ústavní soud $\mathrm{v}$ těchto př́padech sice nerozhoduje plně v souladu s unijním právem, ale nelze očekávat, že by Evropská unie zamýšlela toto jednání nějak postihovat. Také se nezdá, že by tato rozhodovací činnost byla na újmu jednotlivců, spíše naopak, Listina je ve výše uváděných př́padech aplikována jako další v řadě vedle Listiny základních práv a svobod, Úmluvy či jiných lidskoprávních instrumentů. Dochází tím k jistému (dobrovolnému) rozšiřování působnosti unijního práva v České republice, zvláště patrné je to $\mathrm{v}$ oblasti spotřebitelského práva, nicméně je třeba konstatovat, že v rozebíraných prŕpadech Ústavní soud na Listinu jen stručně odkazuje, aniž by ji zevrubně interpretoval a její aplikace ovlivňovala rozhodnutí ve věci.

V některých př́padech naopak Listina není aplikována tak, jak požaduje čl. 51 odst. 1 LZPEU, dochází tedy k porušení unijního práva. Ochrana základních práv jednotlivců je však z materiálního hlediska zajištěna prostřednictvím Listiny základních práv a svobod a mezinárodních úmluv o lidských právech. Nezdá se proto, že by nepoužití Listiny působilo újmu jednotlivcům.

Agentura Evropské unie pro lidská práva monitoruje uplatňování Listiny v jednotlivých členských státech a ve svých zprávách opakovaně upozorňuje na oba fenomény popsané výše, tedy že Listina není vždy aplikována v souladu s čl. 51 odst. 1. Agentura ovšem ve své zprávě z roku 2018 připouští, že není vždy snadné určit hranice působnosti Listiny..$^{50}$ Ostatně jak bylo poukázáno výše, Soudní dvůr EU sám neaplikuje Listinu konzistentně. Někdy působnost Listiny rozšiřuje, někdy čl. 51 odst. 1 interpretuje spíše restriktivně. V některých případech Listinu vůbec nepoužije, ačkoli je dána její působnost. Nebylo by proto zcela spravedlivé kritizovat vnitrostátní soudy za to, že jejich př́stup k čl. 51 odst. 1 LZPEU je někdy problematický.

JUDr. Magdaléna Svobodová, Ph.D.

Právnická fakulta Univerzity Karlovy

svobodom@prf.cuni.cz

49 Bod 20 nálezu IV. ÚS 2370/15.

50 Viz zpráva o základních právech z roku 2018, s. 35. 